\title{
Juks med studier av postoperative smerter
}

\author{
En kjent internasjonal forsker har måttet trekke tilbake 21 av sine mye \\ siterte artikler om medikamentell profylakse og behandling av post- \\ operativ smerte. Hvilken betydning har dette for forskning og klinisk \\ praksis?
}

\author{
Johan Ræder \\ johan.rader@medisin.uio.no \\ Anestesiavdelingen \\ Oslo universitetssykehus, Ullevål \\ 0407 Oslo \\ og \\ Det medisinske fakultet \\ Universitetet i Oslo
}

Under en rutinekontroll av forskningsformalia ved Baystate Medical Center i Springfield, USA, oppdaget man at anestesiologen Scott S. Reuben manglet institusjonens godkjenning forut for to av sine publiserte studier. Ved nærmere ettersyn viste det seg at også datagrunnlaget for studiene var fabrikkert, og at dette trolig i tillegg gjaldt flere andre studier. Reuben innrømmet skyld og har samarbeidet med kontrollmyndighetene, selv om det anføres at han har varierende hukommelse når det gjelder tidligere studier (1). Hittil er 19 artikler og to abstrakter fra perioden 1996-2008 trukket tilbake pga. feil og juks i datamaterialet (2). Det ser også ut til at forskningsmidler fra legemiddelindustrien er kommet på avveie, og at medforfattere er ført opp uten samtykke. Reuben har totalt 72 artikler registrert i Medline, av de gjenværende 53 er han førsteforfatter på 38 .

Saken har klare paralleller til den såkalte Sudbø-saken her i Norge (3). Også her ble data fabrikkert for å sikre publisering i topp anerkjente tidsskrifter. Et hovedmotiv i begge sakene ser ut til å ha vært ønsket om berømmelse og anerkjennelse i fagmiljøet og dermed også i samfunnslivet og privatlivet generelt. Publisering i anerkjente tidsskrifter resulterer i ærefulle invitasjoner og oppdrag til store kongresser, hyppige siteringer av andre og enklere tilgang på forskningsmidler og fasiliteter i fremtiden. I Reubens tilfelle synes også rent privatøkonomiske motiver å ha vært en mulig drivkraft, selv om omfanget her foreløpig ikke er klarlagt.

\section{Faglige konsekvenser}

Vår første tanke bør gå til det rent kliniske, fagmedisinske: Har jukset skadet pasienter?
Vil avsløringen, supplert med tilhørende skepsis til hans øvrige forskningsresultater, føre til endring av våre anbefalinger i den kliniske hverdagen? For å besvare disse spørsmålene er det nødvendig å gå gjennom hva Scott S. Reuben har funnet og publisert av resultater og konklusjoner, samt se på hva andre grupper har publisert om liknende problemstillinger $(1,2)$. Har han resultater som også er funnet av mange andre? Eller har han entydige resultater i en bestemt retning på felter hvor øvrig litteratur spriker? Er det resultater han er helt alene om?

Reuben har stort sett gjort kliniske studier på forskjellige medikamentelle behandlingsopplegg for å lindre smerte etter større ortopedisk-kirurgiske inngrep. Mange studier har vært med nye medikamenter, herunder COX-2-hemmere. Mange av dem har vært firmasponset, og alle har vist signifikant positive resultater og funn. Følgende hovedfunn foreligger i de tilbaketrukne artiklene og skal kort kommenteres: - COX-2-hemmere har smertelindrende effekt etter omfattende ortopedisk kirurgi, de reduserer behovet for samtidig bruk av opioider og dermed bivirkninger fra opioider. Dette er resultater som mange andre grupper har funnet, og som også er funnet for tradisjonelle ikke-steroide antiinflammatoriske midler (NSAID), bl.a. paracetamol og glukokortikoider (4).

- COX-2- hemmere gir bedre langtidsresultater etter omfattende ortopedisk kirurgi (funksjon etter 6-12 md.) enn alternativ analgesi og mindre forekomst av kroniske smerter. Dette er aspekter som er lite undersøkt i detalj av andre, og hvor Reubens positive resultater ikke kan bekreftes ut fra det vi vet i dag. De fleste andre studier konkluderer med at langtidsresultater er svært multifaktorielt betinget og vanskelig kan tilskrives enkeltfaktorer, slik som kortvarig bruk av et enkelt medikament.

- COX-2- hemmere og NSAID-preparater virker bedre hvis de gis for kirurgisk inngrep (preemptiv effekt) enn hvis de gis ut $i$ forlopet eller ved slutten av opera- sjonen. Her spriker øvrig litteratur (5). Tar vi vekk resultatene fra Reubens gruppe, er bildet imidlertid langt mer entydig i negativ retning.

- COX-2-hemmere forsinker ikke beintilheling etter ortopedisk kirurgi. Reuben har publisert resultater som viser at COX2-hemmere gir samme beintilheling som placebo, mens NSAID-midlet ketorolac forverrer tilheling etter skoliosekirurgi. Her foreligger en studie gjort av andre med ketorolac som viser at høy dose forsinker tilheling, mens to nyere studier viser at tilheling ikke forsinkes med normaldose ketorolac (2). Det er en rekke dyreeksperimentelle studier som viser at både NSAID-midler og COX-2-hemmere påvirker beintilheling negativt, men flere studier er nødvendig for å konkludere nærmere om humant klinisk omfang og relevans av dette.

- En rekke stoffer (verapamil, morfin, klonidin, ketorolac) kan settes til lokalanestesi i sårflater og intravenøs regional anestesi med signifikant analgetisk tilleggseffekt. Dette er resultater som til dels synes overraskende ut fra det man vet om smertefysiologi, og som ikke er blitt bekreftet av andre grupper. Disse resultatene bør ikke godtas inntil annet ev. er vist helt klart.

- Oksykodon depottabletter gir bedre analgesi og mindre totalt opioidforbruk gjennom døgnet enn vanlige oksykodontabletter. Dette synes igjen å være et eksempel på at Reuben har publisert mer entydige positive data enn andre, selv om tilsvarende positive aspekter også fremkommer i studier fra andre grupper.

- Preoperativ bruk av venlaflaksin eller pregabalin er gunstig for postoperativ smerte. Mens venlaflaksin er lite testet, viser andres studier av preoperativ pregabalin varierende effekt, mens derimot postoperativ bruk synes mer entydig nyttig.

Hvilke faglige konklusjoner bør vi trekke av dette? For en rekke nye medikamenter (COX-2-hemmere, pregabalin, oksykodon depottabletter) vil bortfall av Reubens arbeider ikke endre hovedkonklusjonene rundt bivirkninger og effekter, men bidra til at de fremstår som noe mindre fordelaktige enn det man har trodd til nå. Konklusjonene i den norske konsensusgjennomgangen av COX-2-hemmere i 2006 endres ikke av Reubens juks (6), selv om disku- 
sjonen rundt kardiovaskulære bivirkninger i dag er mer nyansert ut fra andre, nyere kilder (7).

Enkeltpasienter kan indirekte ha tatt skade av Reubens juks ved at hans positive resultater har satt enkelte legemidler i for positivt lys. Dette kan ha bidratt til at disse medikamentene er blitt ordinert oftere og for lengre tid enn indisert, med påfølgende mulige bivirkninger og skade hos enkelte.

\section{Andre konsekvenser}

Det er ingen tvil om Reubens juks også har påført forskning, undervisning og klinisk rådgivning betydelig skade og merarbeid. Det blir nå viktig å gå gjennom og stille spørsmål ved mange oversiktsartikler, lederartikler, metaanalyser og konklusjoner som andre har skrevet, hvor Reubens arbeider er referert. De siste sju årene er hans tilbaketrukne arbeider sitert 30-40 ganger hvert år i anerkjente tidsskriftartikler internasjonalt (8). I enkelte metaanalyser har Reubens resultater utgjort en viktig del av datagrunnlaget i en bestemt retning. Når disse nå faller bort, kan konklusjonen av hele metaanalysen bli endret (9). Et annet aspekt er dessverre at når en tilsynelatende god (men falsk), positiv studie foreligger innenfor et felt, vil andre ambisiøse forskningsgrupper ikke alltid bry seg med å lage en ny studie om det samme. Skulle de likevel gjøre det og resultatet bli negativt og riktig, så vil de kanskje få vanskeligheter med å publisere dette. Dette poenget prøver internasjonale redaktører å ta fatt $\mathrm{i}$. Man har oppfordret forskere til å etterprøve Reubens hypoteser og sagt at artikler og hypoteser på dette grunnlag vil bli betraktet som helt nye og interessante i publiseringssammenheng (8).

En slik sak reiser også en rekke problemstillinger rundt medforfatterskap, medikamentprodusenters rolle, tidsskriftenes publiseringskontroller og rutiner for forskningskontroll generelt. Tidsskriftenes kvalitetskontroll innebærer systemer med redaksjonell vurdering basert på fagfellekommentarer fra eksperter innen aktuelle felter. Fokus ligger på hvorvidt artikkelen presenterer gode hypoteser, adekvate forskningsmetoder samt riktig tolking og drøfting av data og funn. Dette har vært basert på tillit til at det som faktisk står i et innsendt manus, ikke har vært juks eller løgn. Det har vært tilfeller hvor redaktører og fagfelleekspertise har ment at data har vært for gode til å være sanne, men slike spørsmål er svært vanskelige å ta opp med mindre det er helt opplagt.

For store, industribaserte studier i forkant av registrering av nye medikamenter har man imidlertid gode revisjonssystemer for validering av data. FDA eller andre legemiddelmyndigheter kan komme uanmeldt til forskeren og forlange innsyn i all originaldokumentasjon for å sikre at registrerte data faktisk stemmer. Reuben har også deltatt i slike studier, men ingen av disse er på listen over tilbaketrukne arbeider. Industrien selv passer også godt på slike registreringsstudier, det er helt ødeleggende å få medansvar for datajuks med et medikament som man prøver å få registrert. Muligheten for tilsvarende revisjon av de fleste andre typer studier er imidlertid svært liten. Reubens sykehus oppgir at de foretar revisjon med stikkprøver på om lag $5 \%$ av sine studier, og Reuben kunne altså holde på i minst 12 år før han ble avslørt.

Medforfattere kan også representere en potensiell kilde for kvalitetskontroll av data. Selv om moderne forskning ofte foregår i store grupper hvor hver aktør har sin klart avgrensede rolle i prosjektet, vil medforfatterne forventes å kjenne problemområdet så godt at man bør kunne få mistanke, i hvert fall der hvor flere aktører deltar i den primære bearbeidingen av data. Typisk både for den norske Sudbø-saken og Reubensaken er imidlertid at jukseren var hovedforfatter og tok på seg «jobben» med å bearbeide alle grunndata fra mange kilder inn i et regneark. Resultatet ble presentert for medforfatterne i manipulert form for videre bearbeiding.

\section{Veien videre}

Mens man bør gå grundig gjennom nåværende rutiner for kvalitetskontroll av klinisk forskning, er det imidlertid viktig at man ikke etablerer et unødig tungt byråkrati som tar motet fra forskere som vil gjøre viktige og spennende studier. Dessverre har vi i Norge de senere årene sett at mange forskjellige instanser og nivåer bygger opp kontrollrutiner og forskjellige skjemaer om samme tema, som krever unødig mye forarbeid og byråkratisk kompetanse hos forskerne. Det bør arbeides for en samordning og forenkling på en del felter her, samtidig som det bør settes sterkere søkelys på revisjon og kontroll av grunnlagsdata.

Det tok altfor lang tid å avsløre datajukset til Scott Reuben. Likevel er det en trøst å se at en god, gammel regel fremdeles gjelder og bør kunne beskytte oss i noen grad mot liknende saker i fremtiden: Nye forskningsfunn og erkjennelser $m a ̊$ bekreftes av flere, uavhengige grupper før det får konsekvenser for daglig behandling av pasienter.
Oppgitte interessekonflikter: Johan Ræder har vært medlem av Advisory Board for MSD International, Novartis International og Pfizer Norge, har deltatt i klinisk utprøving for Pfizer og MSD og har mottatt reisestøtte fra MSD, Pfizer og Novartis til internasjonale møter og kongresser.

\section{Litteratur}

1. Shafer SL. Tattered threads. Anesth Analg 2009; 108: 1361-3

2. White PF, Kehlet H, Liu S. Perioperative analgesia - what do we still know? Anesth Analg 2009; 108: 1364-7

3. Haug C. For godt til å være sant. Tidsskr Nor Lægeforen 2006; 126: 1891.

4. Dahl V, Raeder JC. Non-opioid postoperative analgesia. Acta Anaesthesiol Scand 2000; 44 1191-203.

5. Ong CK, Lirk P, Seymour RA et al. The efficacy of preemptive analgesia for acute postoperative pain management: a meta-analysis. Anesth Analg 2005; 100: 757-73.

6. Reikvam $\AA$, Hexeberg S, Kvien TK et al. Klinisk bruk av COX-hemmere - en konsensus. Tidsskr Nor Lægeforen 2006; 126: 591-5.

7. Hermann M. Cardiovascular risk associated with nonsteroidal anti-inflammatory drugs. Curr Rheumatol Rep 2009; 11: $31-5$

8. Eisenach JC. Data fabrication and article retraction. Anesthesiology 2009; 110: 955-6.

9. Kranke P, Apfel CC, Eberhart LH et al. The influence of a dominating centre on a quantitative systematic review of granisetron for preventing postoperative nausea and vomiting. Acta Anaesthesiol Scand 2001; 45: 659-70.

Manuskriptet ble mottatt 12.4. 2009 og godkjent 28.5. 2009. Medisinsk redaktør Anne Kveim Lie. 